\title{
Morbidity of British coal miners in 1961-62
}

\author{
F. D. K. LIDDELL \\ Department of Epidemiology and Health, McGill University, Montreal, Canada
}

Liddell, F.D.K. (1973). Brit. J. industr. Med., 30, 1-14. Morbidity of British coal miners in 196162. The British coal mining population in 1961 is described, in terms of the 29084 men covered in a $5 \%$ sample census, by age, type of employment, coalfield, size of community, degree of mechanization, and other factors. Over a quarter of the men were in jobs not considered specific to coalmining, although nearly half of such men were working underground. The Ministry of Pensions and National Insurance provided records of over 34000 spells of incapacity due to sickness for these men. Miners were found to suffer much more incapacity for work than men in other employment, even in those non-mining tasks considered to be very arduous. Among miners at the face, elsewhere underground, and on the surface, the lowest paid had the highest rate of incapacity. Incapacity from most causes was also found to vary between coalfields and with size of residential community, and to depend on the men's financial responsibilities, category of pneumoconiosis, and depth of working, but not on the degree of mechanization. A relationship was observed between seam height and the incidence of new spells of beat knee.

The numbers employed in coalmining in Britain are now 280000 compared with over 700000 in 1958 ; but this remains a very large industry, vital to the country's economy. The health of the miner is, therefore, a matter of considerable importance. Ever since comparative studies have been made, miners have appeared to have high rates of incapacity for work. For example, Cornwall (1962) reports that "the high claim rate for miners seems to have been very well known . . . throughout very nearly the whole of the nineteenth century'. However, claims for benefit is only one indicator of sickness; others are frequency of consulting medical practitioners, days for which benefit is paid, or number of illnesses reported in a period. None is an unequivocal definition of sickness, and the same illness may have quite different effects on the ability to work in different occupations. Indeed, any arduous occupation can be performed only by fit men; the less fit may have to move to lighter work. Additional problems arise from the different age structures of the various occupational groups and the great variation in sickness rates with age.
Earlier studies (e.g., Logan and Brooke, 1957; Liddell, 1962) have also suffered from misstatements of occupation on claims and on census schedules.

In a survey (Liddell, 1962) of coal miners' morbidity in 1951 and 1955-56, it was concluded that the hazards to the miners' health were much greater than normal, leading to very high rates of incapacity from injury and the prescribed occupational diseases; and with regard to other sickness, too, I suggested that most of the reported excess could be accounted for by the exceptional physical demands of mining.

The present study is of incapacity for work for which sickness benefit was paid. Its main advantage over previous studies is that a single statement of occupation was made about each man in the study so that if there were any inaccuracy it would affect his classification both in the denominators and in the numerators of sickness rates.

\section{Material}

A sample census was taken of all National Coal Board (NCB) employees at 5 June 1961. The basis of the sample 
was that used in the Ministry of Pensions and National Insurance (MPNI, 1965) enquiry into incapacity for work, i.e., it included all men with National Insurance numbers ending in 4 or 8 with the suffix B; the sample fraction was $5 \%$. The information collected for each person consisted of name, address (which was coded by local offices of the MPNI), date of birth, occupation, and income tax code number. Checks were made locally that the coverage at each managerial unit was in accordance with expectation, and the 33156 cards involved were edited by both the NCB and the MPNI. Information was then obtained from the Colliery Profile (Liddell, 1955) on such matters as seam thickness and degree of face mechanization on a colliery basis, and this was added to the census cards for every man at each particular colliery. Details of any $x$-ray in the NCB Periodic $X$-ray Scheme (Rogan, 1964) were added. Finally, information about each spell of incapacity attracting sickness benefit for all the men in the NCB census was made available. The Appendix gives details and explains why many NCB tabulations would not be comparable with those of the MPNI (1965): the grouping of causes of incapacity and the bases of the inception rates were different.

The population of industrial males employed by NCB is described in Tables 1 to 6 . These are based on the 29084 such men who, as described in the Appendix, were finally embraced in the sample census. The incapacity for work of this population is described in Tables 8 to 11. The MPNI information was restricted to the age range 15 to 64 , and so those in the population over 64 were excluded from this stage of the study, which is based on records for 28604 men: details are in the Appendix, which also gives definitions of the groupings of factors.

\section{Occupational codes}

Occupational information was provided as reference numbers in the NCB National Schedule of Occupations, extended to cover under-officials, juveniles, and weekly paid industrial staff. For each of the well over 500 jobs listed we agreed with MPNI, before the enquiry started, a translation into the General Register Office (GRO, 1960) Classification of Occupations in which the codes for specifically coalmining occupations are:

010 Coal mine-face workers

011 Coal mine-other underground workers

012 Coal mine-workers above ground

013 Coal miners (so described)-used here only for those reported from NCB sources simply as 'juveniles' because the specific work they carried out could not have been determined.

\section{The coalmining population in 1961}

As a preliminary, Table 1 gives numbers of men in the NCB census, the MPNI enquiry, and the national census. The first column shows that over a quarter of the industrial males employed by NCB were in occupations which do not code to 010-013. Those over 64 were excluded from the second column, which can be compared with the third, taken from MPNI (1965, p. 16). The MPNI figures are slightly higher because, although they exclude men of 64 at the end of 1961, they include men at licensed mines, forming $2 \%$ of the industry. Agree-
TABLE 1

The Population Studied

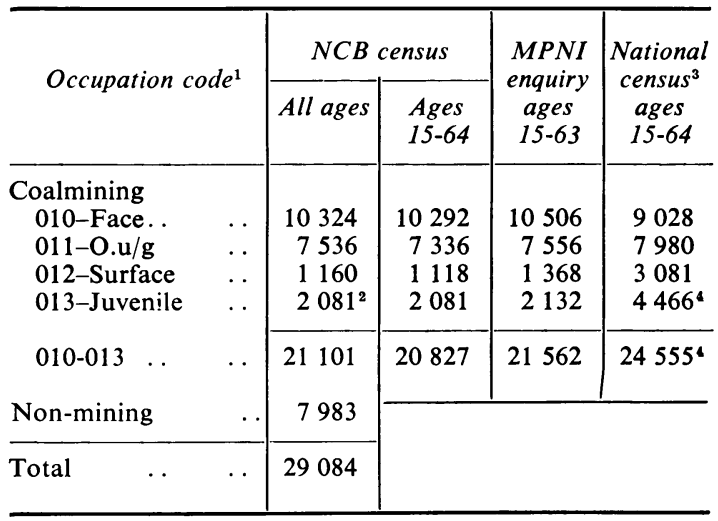

${ }^{1}$ See text for explanations of abbreviations.

${ }^{2} J u v e n i l e s$, not allocatable to specific occupations.

'Those 'economically active', scaled to the same sampling fraction.

${ }^{4}$ Includes 014 ('workers below ground not elsewhere classified', numbering 416 in' MPNI enquiry).

ment with figures from the national census (General Register Office, 1966; General Register Office, Edinburgh, 1966) is less close: there, code 012 would include 'general workers' on the surface, 1026 of whom were coded by MPNI (and so NCB) as labourers (188); in code 013, the majority of the 4466 were not juveniles so that the excess seems to have been due largely to inadequate descriptions. The reason for the overall excess of about $10 \%$ of coal miners in the national census may lie in unemployment or in misleading or uncodable statements on census schedules.

In Table 2, the industrial males are classified by both type of employment in mining and GRO code. One-third of elsewhere-underground workers and over three-quarters of surface workers were in occupations not considered to be specifically coalmining. (The main such occupations are indicated in the Appendix.) Table 2 also gives the average age of each group of men. Not surprisingly, the weekly paid industrial staff were the oldest group followed by under-officials and surface workers, and the face workers were the youngest (apart from the juveniles); nevertheless, one face worker in eight was over 55.

The coalfields of Britain were in 1961 administered in nine divisions (Table 3), ranging from the small Kent coalfield to the very large administrative units covering the Yorkshire and East Midlands coalfields. Table 3 also shows wide differences in distributions over size of the communities in which the men lived: in the North Western and West Midlands Divisions, over $40 \%$ lived in conurbations or large towns, whereas in the South Western Division over half 
TABLE 2

GRO OCCUPATION CODES FOR TYPES OF MINING EMPLOYMENT

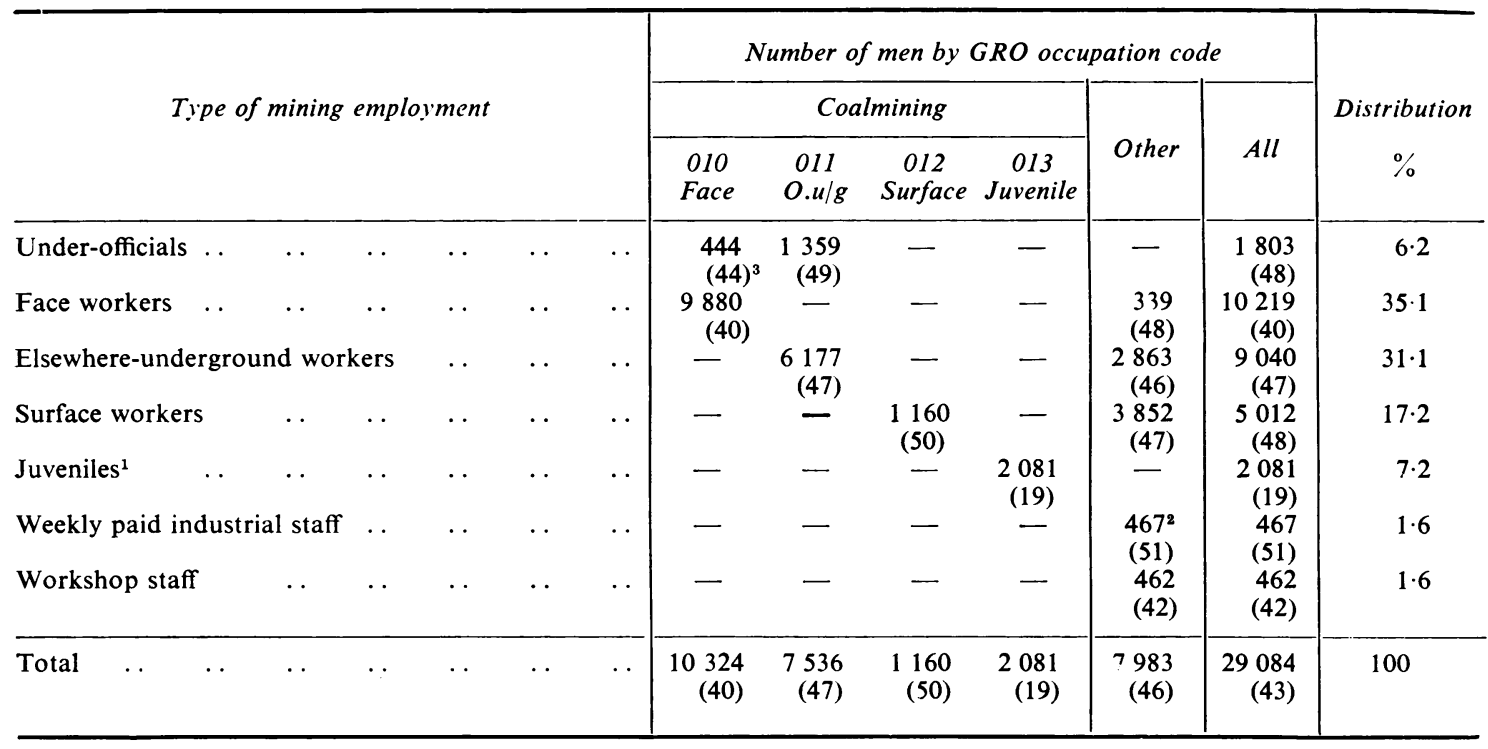

${ }^{1}$ Not allocatable to specific occupations.

${ }^{2}$ Not allocatable to specific codes, but mainly in occupations other than those that code to 010,011 , or 012 .

${ }^{3}$ Figures in parentheses are average ages.

lived in small towns, and in Scotland over half lived in rural areas. On the other hand, distributions by type of employment were more consistent. For example, face workers accounted for approximately the same proportion of all industrial males over the nine divisions, ranging only from 32 to $37 \%$. The proportions of both under-officials and weekly paid industrial staff, who are normally of foreman status, varied more, from (combined) $6.2 \%$ in the South
Western Division to $10.0 \%$ in Northumberland and Cumberland.

Table 4 summarizes some other coalfield differences. The size of colliery varied greatly between and within divisions: about a quarter of miners worked at collieries employing either less than 500 men or more than 2000 . Several coalfields had both very shallow and very deep workings. However, there were no collieries in Northumberland and

TABLE 3

Geographical Region and Size of CoMmunity

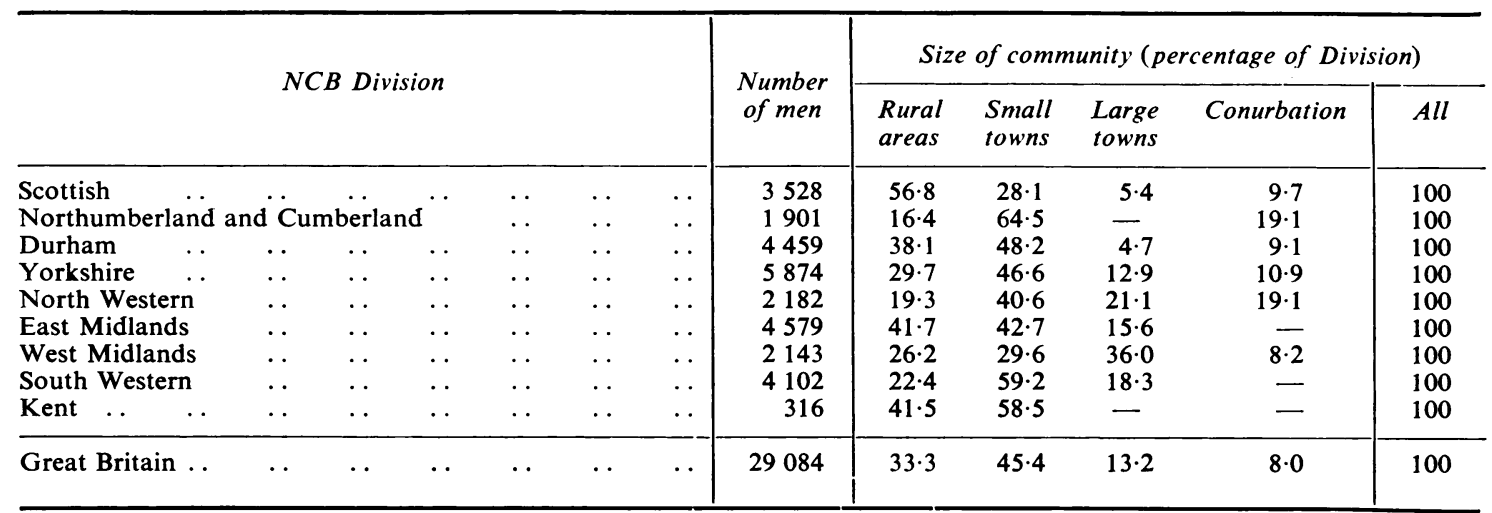


TABLE 4

Size of Colliery, Depth of Working, Posture at Work and Degree of Mechanization

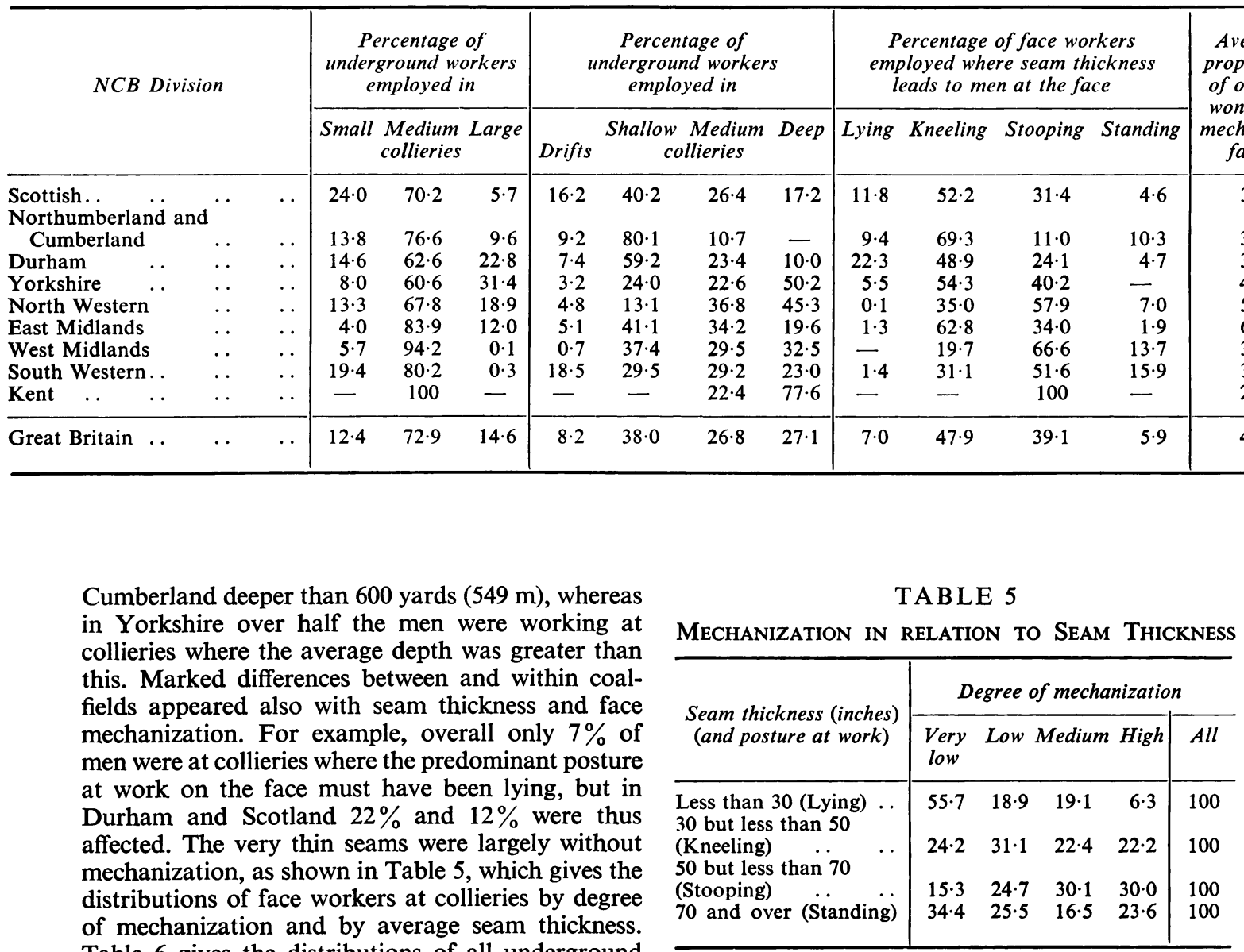
Table 6 gives the distributions of all underground workers by specific job, according to the degree of mechanization. Although overall there was a slight tendency for the percentage of face workers to decrease as the degree of mechanization increased, the tendency was by no means consistent in all coalfields. The distribution of jobs did, however, depend on the degree of mechanization. As an example, there was an increasing proportion of loader operators with higher degrees of mechanization while the proportion of colliers decreased. On the other hand, the age distribution of face workers was very similar for each degree of mechanization. The more highly mechanized faces tended to have lower accident rates, but not in all coalfields; indeed, in Yorkshire this trend was reversed. There was also a tendency for collieries with a very low degree of mechanization to have low absence rates too. Finally, Fig. 1 gives distributions of all industrial males by age and financial responsibilities; this shows the clear relationships expected.

\section{Miners' incapacity for work}

The record for each man contained not only personal data and information in relation to the colliery where he worked, but also details of each spell of incapacity in the year 1961-62 for which sickness benefit was paid to him, the spell having been classed by cause and length (see Appendix). So, to determine the sickness experience of any group of men, it was necessary only to select the records for the group, to count (for denominator) the men in the group, and (for numerators) the days and spells of incapacity by length and cause. Thus we could find three rates (either for specific causes or for all causes): total days of incapacity per 100 men; number of spells (any length) of incapacity per 100 men; number of long spells of incapacity per 100 men. Groups were then compared, after subgrouping by age, in terms of: 
TABLE 6

Mechanization in relation to Jobs, Accidents, and Absence

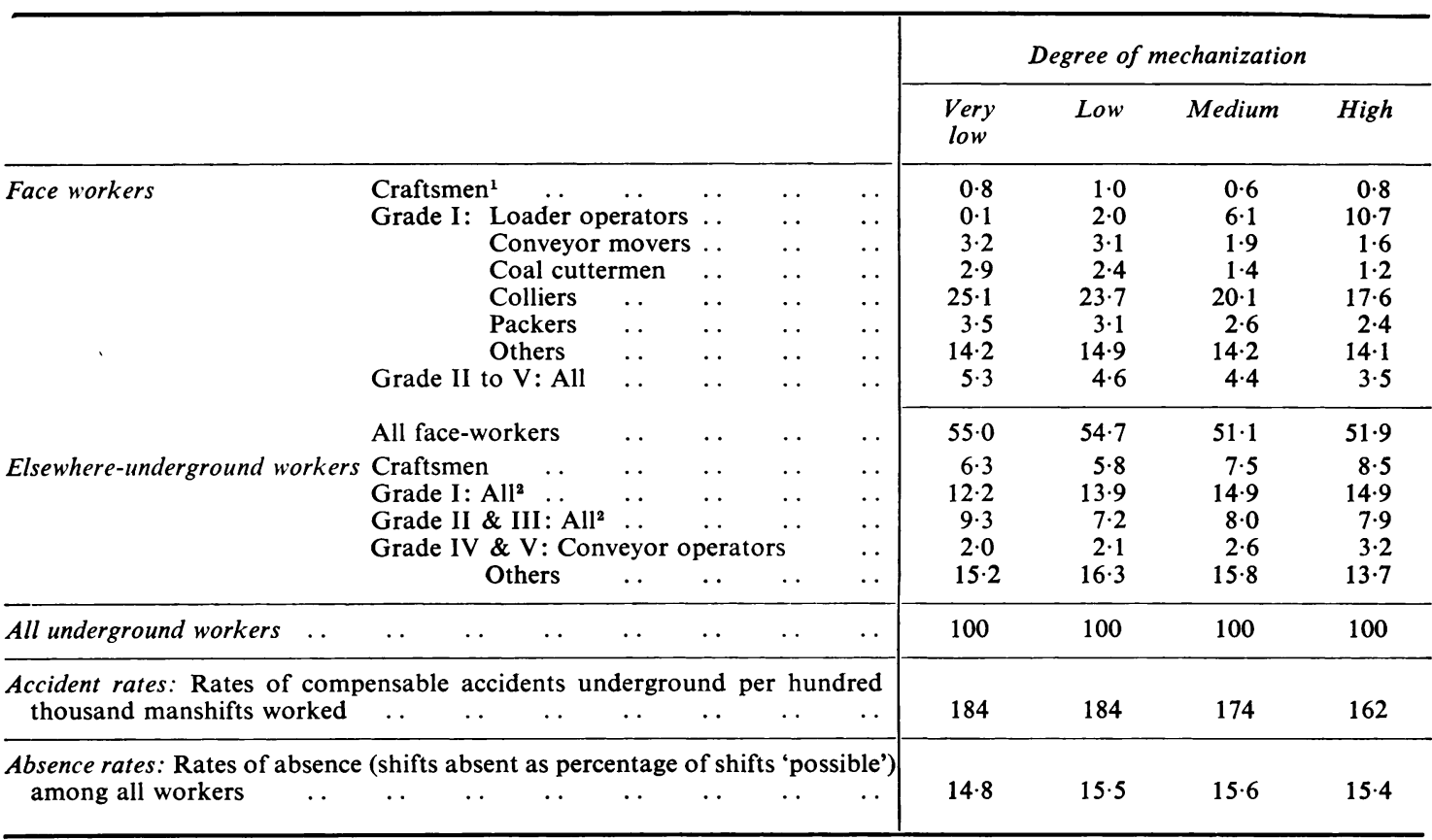

${ }^{1}$ Electricians, fitters, etc., paid at higher rates than others at the same place of work.

${ }^{2}$ There is a small degree of overlap in these classes.

(a) all three age-specific rates of incapacity for all causes;

(b) (for comparisons within the mining industry) standardized incapacity ratios (spells), called SIRs and described in the Appendix.
To put the information on incapacity among miners into perspective, Table 7 presents material extracted from the MPNI (1965, p. 70) report on their own enquiry. The rates for coalmining occupations are transcriptions; the others were obtained

TABLE 7

INCAPACITY IN RELATION TO ARDUOUSNESS OF WORK (Days of incapacity per $100 \mathrm{men}$ )

\begin{tabular}{|c|c|c|c|c|c|c|c|c|c|c|c|c|}
\hline & & \multirow{2}{*}{\multicolumn{5}{|c|}{ Occupation }} & \multicolumn{5}{|c|}{ Age group } & \multirow{2}{*}{$\begin{array}{l}\text { Equivalent } \\
\text { average } \\
\text { ratio }\end{array}$} \\
\hline & & & & & & & $15-24$ & $25-34$ & $35-44$ & $45-54$ & $55-63$ & \\
\hline \multicolumn{2}{|c|}{$\begin{array}{l}\text { Coalmining } \\
\text { 010-Face } \\
011 \text {-O.u/g } \\
\text { 012-Surface }\end{array}$} & $\begin{array}{l}\cdots \\
\cdots \\
\cdots\end{array}$ & $\begin{array}{l}. \\
\cdots \\
\cdots\end{array}$ & $\begin{array}{l}\cdots \\
\cdots \\
\cdots\end{array}$ & $\begin{array}{l}\cdots \\
\cdots \\
\cdots\end{array}$ & $\begin{array}{l}\cdots \\
\cdots \\
\cdots\end{array}$ & $\begin{array}{ll}1213 \\
1138 \\
1432 \\
\end{array}$ & $\begin{array}{l}1460 \\
2035 \\
2027\end{array}$ & $\begin{array}{l}1625 \\
2017 \\
1307 \\
\end{array}$ & $\begin{array}{l}2004 \\
2620 \\
2546\end{array}$ & $\begin{array}{l}2657 \\
3607 \\
3833 \\
\end{array}$ & $\begin{array}{l}195 \\
248 \\
242\end{array}$ \\
\hline 010-012 & . & . & . & . & . & . & 1197 & 1634 & 1733 & 2311 & 3370 & 223 \\
\hline $\begin{array}{l}\text { Non-mining } \\
\text { Very arduou } \\
\text { Arduous } \\
\text { Medium } \\
\text { Light } \\
\text { Sedentary }\end{array}$ & $\begin{array}{l}\text { us } \\
\cdots \\
\cdots \\
\cdots \\
\cdots\end{array}$ & $\begin{array}{l}\cdots \\
\cdots \\
\cdots \\
\cdots\end{array}$ & $\begin{array}{l}\cdots \\
\cdots \\
\cdots \\
\cdots \\
\cdots\end{array}$ & $\begin{array}{l}\ldots \\
\cdots \\
\cdots \\
\cdots\end{array}$ & $\begin{array}{l}\cdots \\
\ldots \\
\ldots \\
\ldots\end{array}$ & $\begin{array}{l}\ldots \\
\cdots \\
\cdots \\
\cdots\end{array}$ & $\begin{array}{l}610 \\
604 \\
561 \\
467 \\
416\end{array}$ & $\begin{array}{l}757 \\
681 \\
566 \\
405 \\
385\end{array}$ & $\begin{array}{l}858 \\
827 \\
683 \\
505 \\
462\end{array}$ & $\begin{array}{r}1133 \\
1147 \\
966 \\
707 \\
629\end{array}$ & $\begin{array}{ll}2026 \\
2004 \\
1 & 747 \\
1 & 355 \\
1 & 245\end{array}$ & $\begin{array}{r}117 \\
114 \\
98 \\
75 \\
68\end{array}$ \\
\hline All occupation & & . & . & . & . & . & 554 & 584 & 711 & 983 & 1771 & 100 \\
\hline
\end{tabular}



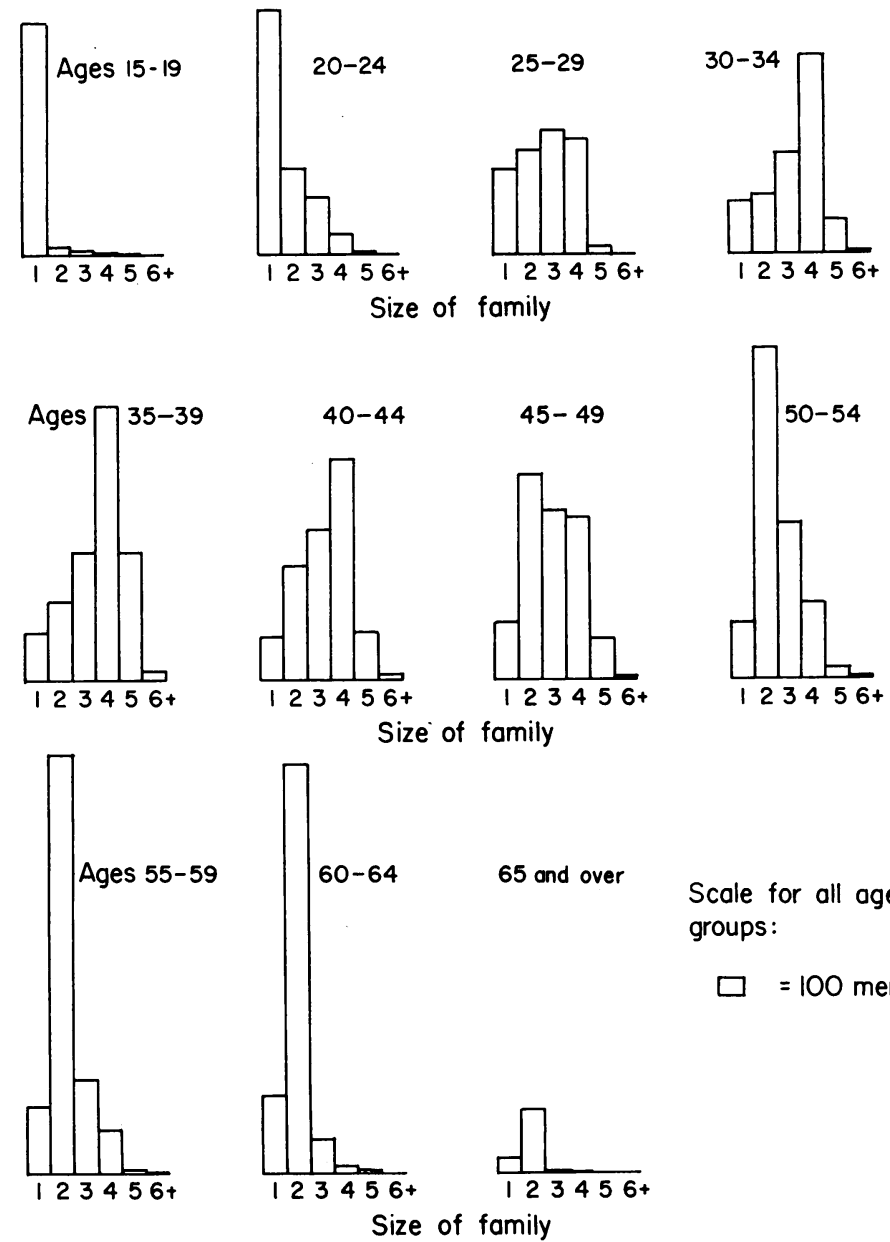

Scale for all age groups:

$\square=100$ men

FIG. 1. Age, and size of family (see Appendix).

by classifying (Murray, 1967) each of the nearly 200 occupations by heaviness of work. Within each occupation rates increased with age: thus the differences between occupations can be summarized fairly in standardized ratios, as in the final column of Table 7, where Yule's (1934) method was used, and where ratios are expressed in relation to the rate for all 605396 men in the MPNI enquiry with adequate job description. The amount of incapacity was clearly related to the arduousness of non-mining work; in mining occupations there was much more incapacity even than among men in the very arduous group of non-mining occupations. This pattern is seen in every age group.
Ratios on the same basis ${ }^{1}$ are quoted in Table 8 , using material from the NCB enquiry. Among coalmining occupations (010-012), there was a marked gradient from a ratio of 198 at the face, through 251 to 273 at the surface. Under-officials

${ }^{1}$ The grouping of occupations for computer purposes in the NCB enquiry was to allow comparisons within place of work in terms of rates of pay. Thus some of the ratios in Table 8 are estimates. However, they are all considered reasonably reliable except the bracketed figure, which is based on very few men. Further, because only five under-officials were under 25 , the ratio quoted for this group is based on ages 25 to 64 . 
TABLE 8

Incapacity Ratios (Days) by Type of Mining Employment and Coding of Occupations

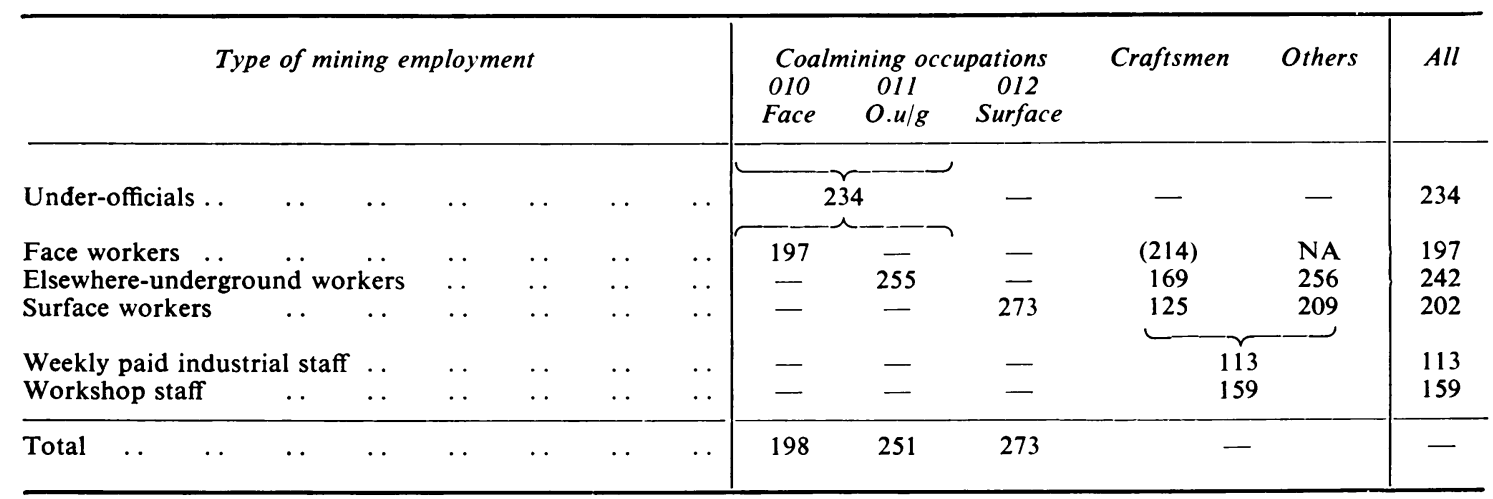

All men in MPNI enquiry $=100$.

had a ratio between the two classes of men they supervise; however, under-officials under 35 had considerably higher rates of incapacity than either class in the same age groups. Where rates for craftsmen $^{1}$ are reasonably reliably assessed, they were substantially lower than for other men at the same places of work. Workshop staff had a ratio between that for surface craftsmen and workers on the surface in other 'non-mining' occupations. Weekly paid industrial staff had the lowest ratio, similar to that for arduous work in other industry.

${ }^{1}$ See Table 6.
So far, incapacity has been assessed in terms of days so that comparisons could be made with the findings of the MPNI enquiry. Figure 2 re-presents the comparison between types of mining employment giving also rates based on spells of incapacity of all lengths and of long duration. The patterns are most consistently maintained for spells of incapacity of all lengths, so age-standardization is most meaningful with this index (Liddell, 1960). In what follows, SIRs (see Appendix) based on this index only are presented, but comment is made on findings with the other indices. Because of the very large numbers involved, most of the quoted SIRs (i.e., those outside the range 98 to 102) would be
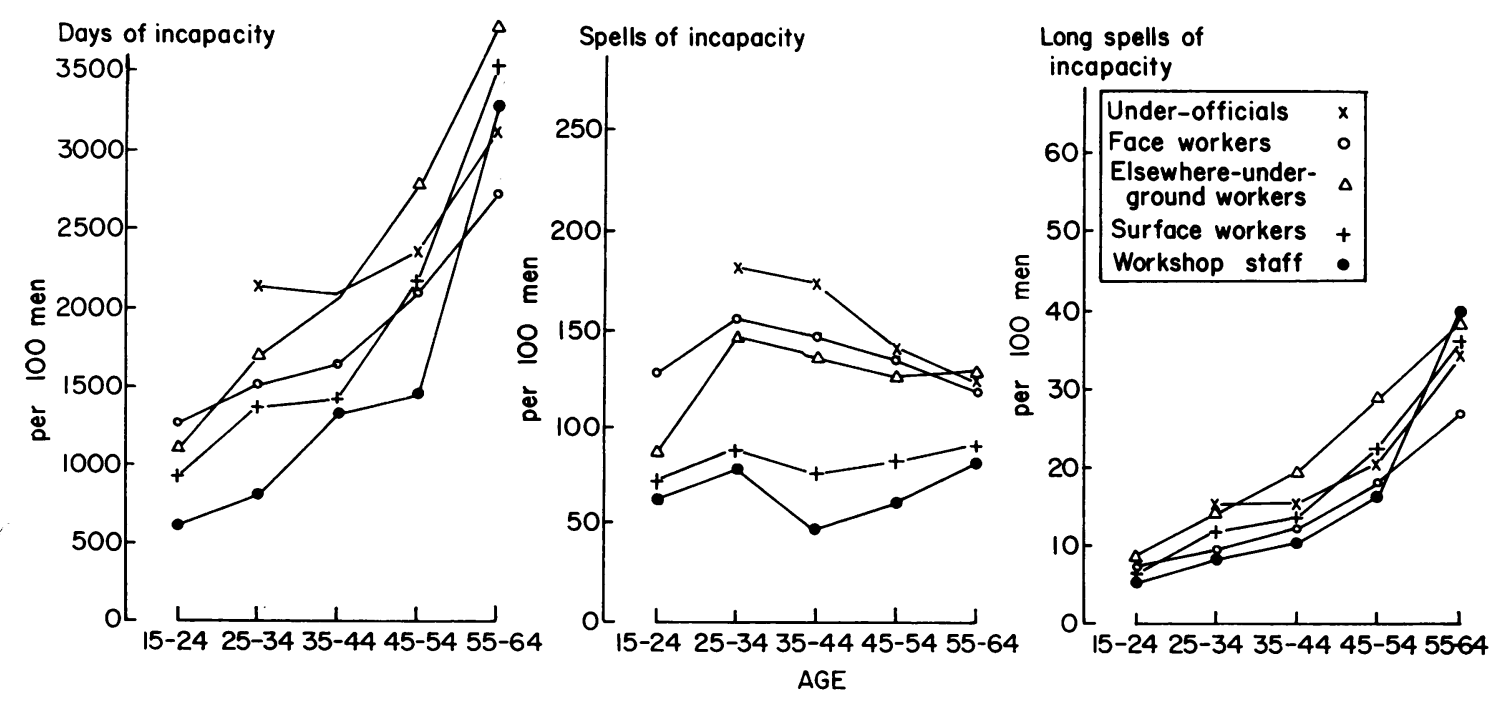

FIG. 2. Job, age, and incapacity on three bases. 
assessed as 'significantly' different from 100 at the conventional level of statistical significance: this concept is, as so frequently in epidemiology, irrelevant here.

\section{TABLE 9}

INCAPACITY (SIRS) ${ }^{1}$ IN RELATION TO MINING JOB

\begin{tabular}{|c|c|c|c|c|c|}
\hline \multicolumn{3}{|c|}{ Type of mining employment } & $\begin{array}{l}\text { Lower } \\
\text { grades }\end{array}$ & $\begin{array}{l}\text { Higher } \\
\text { grades }\end{array}$ & Craftsmen \\
\hline Under-officials & . & . & \multicolumn{3}{|c|}{120} \\
\hline $\begin{array}{l}\text { Face workers } \\
\text { Elsewhere-underg }\end{array}$ & ound & .. & 118 & 108 & 99 \\
\hline $\begin{array}{l}\text { workers } \ldots \\
\text { Surface workers }\end{array}$ & & $\begin{array}{l}\text {. } \\
\ldots\end{array}$ & $\begin{array}{r}125 \\
90\end{array}$ & $\begin{array}{r}102 \\
51\end{array}$ & $\begin{array}{l}82 \\
49\end{array}$ \\
\hline \multicolumn{3}{|c|}{$\begin{array}{l}\text { Weekly paid industrial and } \\
\text { workshop staff }\end{array}$} & \multicolumn{3}{|c|}{59} \\
\hline
\end{tabular}

${ }^{1}$ See Appendix.

Table 9 compares occupations within place of work, grouping by grade (indicating wage rates), and giving SIRs for under-officials and weekly paid industrial staff. At each place of work craftsmen had lower incapacity than men in higher grades, and those in the lowest grades had the highest rates. The findings were fairly similar when incapacity was measured in days or in long spells. Table 10 relates incapacity to several other factors. An asterisk (*) indicates that incapacity measured in days and in long spells also differed from 'normal' to more or less the same extent; the one exception is that the West Midlands Division had close to average rates with these indices. The differences in incapacity associated with certain factors might be expected to be due partly to the marked differences in the way in which these factors were manifest in the different coalfields. We have therefore examined the interactions, i.e., the extent to which the patterns of incapacity were distorted in cross-classifications, as follows: each factor (as in Tables 9 and 10) within coalfields; each factor except pneumoconiosis within size of community; and pneumoconiosis by job. An asterisk $\left(^{*}\right)$ in Table 10 also indicates that the pattern for the specific factor was reasonably maintained in the cross-classifications; as the only exception, however, it was found that incapacity increased steadily with depth of working in only half the coalfields and in three community sizes, being reversed in the small towns.

The effects marked with an asterisk (*) in Table 10 thus seem to be definite and more or less independent. We therefore continued by studying cause-specific SIRs for each factor separately. The rates used in the calculations are given in Table 11, by cause and age. 'Reference diseases' were introduced for a methodological check (Liddell, 1962), which is discussed in the Appendix.

Job Under-officials had more than average incapacity by most causes. Face workers in higher grades had slightly higher than average SIRs except for 'other respiratory illnesses', psychoses, and psychoneuroses. The other groups of face workers were too small to justify breakdown by cause. For workers elsewhere underground, the ratios for each specific cause group tended to reflect those for all causes, although there appeared to be rather more 'other respiratory illnesses' and acute bronchitis among higher and lower grade workers respectively. The other groups of men had cause-specific incapacity fairly similar to that for all causes.

TABLE 10

INCAPACITY (SIRs) IN RELATION TO SELECTED FACTORS

\begin{tabular}{|c|c|c|c|c|c|c|c|c|c|c|c|}
\hline \multicolumn{2}{|c|}{ Geographical location } & \multicolumn{2}{|l|}{$\begin{array}{l}\text { Size of } \\
\text { community }\end{array}$} & \multicolumn{2}{|c|}{$\begin{array}{l}\text { Depth of } \\
\text { working }\end{array}$} & \multicolumn{2}{|c|}{$\begin{array}{l}\text { Degree of } \\
\text { mechanization }\end{array}$} & \multicolumn{2}{|c|}{$\begin{array}{c}\text { Financial } \\
\text { responsibility }\end{array}$} & \multicolumn{2}{|c|}{$\begin{array}{c}\text { Category of } \\
\text { pneumoconiosis }\end{array}$} \\
\hline$N C B$ Division & $S I R$ & & $S I R$ & & $S I R$ & & $S I R$ & & SIR & & $S I R$ \\
\hline $\begin{array}{l}\text { Scottish } \\
\text { West Midlands }\end{array}$ & $\begin{array}{l}70^{*} \\
72^{*}\end{array}$ & Rural areas & $78^{*}$ & V. shallow & $93^{*}$ & V. low & 100 & Single & 88 & & 96 \\
\hline $\begin{array}{l}\text { Northumberland and } \\
\text { Cumberland }\end{array}$ & $84^{*}$ & Small towns & 110 & Shallow & 97 & Low & 106 & $\begin{array}{l}\text { Married, } \\
0 \text { children }\end{array}$ & 93 & & 108 \\
\hline $\begin{array}{l}\text { East Midlands } \\
\text { Durham }\end{array}$ & $\begin{array}{l}93 \\
97\end{array}$ & Large towns & 107 & Deep & $112^{*}$ & Medium & 102 & Married, & 103 & $\begin{array}{l}2,3 \text { or } \\
\text { PMF }\end{array}$ & $129 *$ \\
\hline $\begin{array}{l}\text { North Western } \\
\text { South Western } \\
\text { Yorkshire }\end{array}$ & $\begin{array}{c}98 \\
124^{*} \\
125^{*}\end{array}$ & Conurbations & 91 & V. deep & N.A. & High & 99 & $\begin{array}{l}1 \text { child } \\
\text { Married, } \\
2 \text { or more } \\
\text { children }\end{array}$ & $118^{*}$ & & \\
\hline
\end{tabular}




\section{TABLE 11}

InCAPacity by Cause of All Industrial Males, 15-64, in NCB ENQuiry (Numbers of spells of incapacity per 100 men, by selected cause, in each age group)

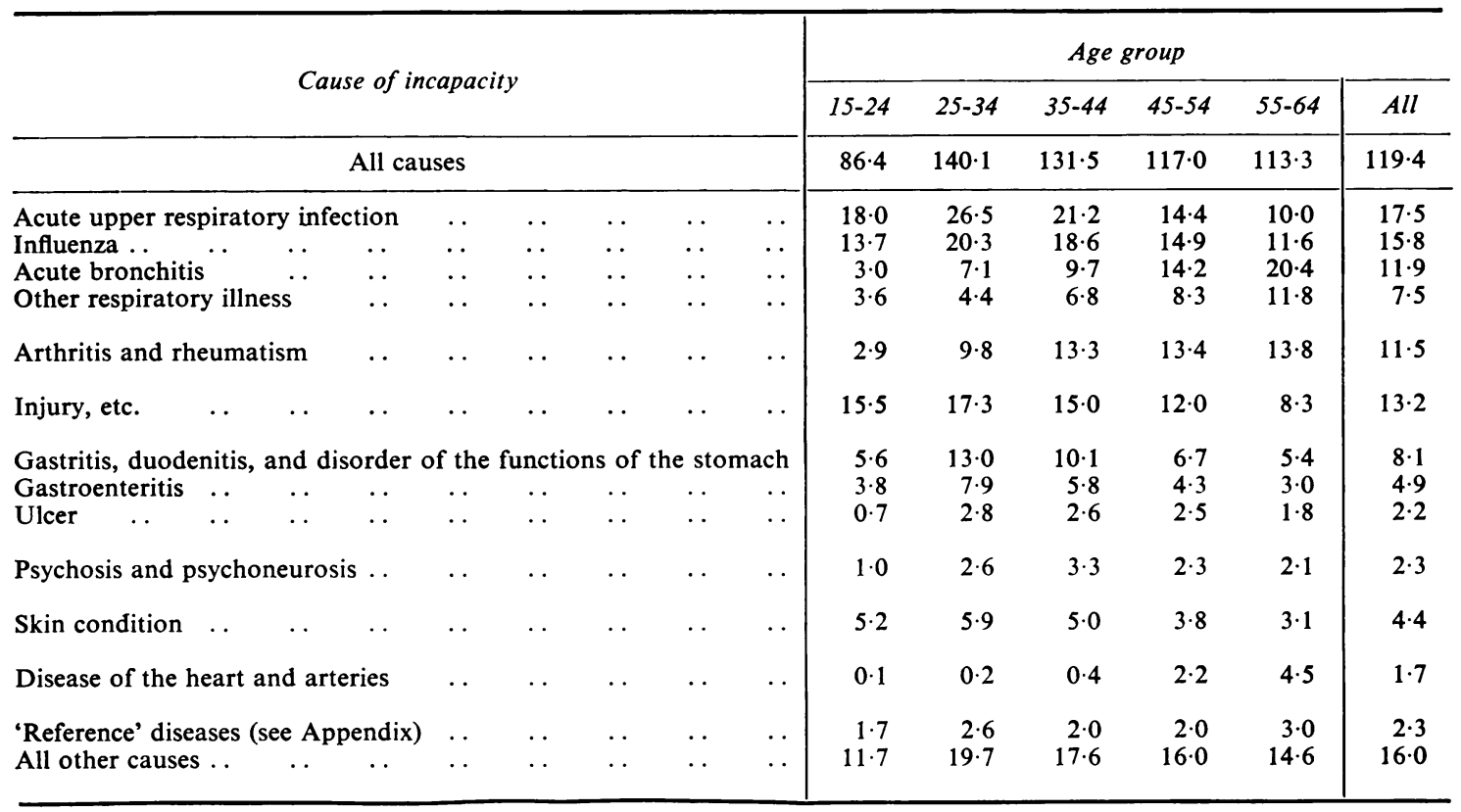

Coalfield Scottish, West Midlands, and Northumberland and Cumberland Divisions had below average incapacity for each cause examined. Yorkshire and South Western Divisions had high incapacity rates for all specific causes, except that in the latter, SIRs for arthritis and rheumatism, gastroenteritis, and skin conditions were close to 100 .

Size of community Men living in rural areas had low incapacity for each separate cause. Conurbations also tended to have low ratios (between 80 and 100) for each cause, exceptions being slightly higher values for ulcers and 'other causes'. Large towns had consistently high cause-specific SIRs, but for small towns the variation was more considerable.

Depth of working For the very shallow collieries, SIRs were a little lower than 100 , except that those for influenza and for ulcers were 101; for shallow collieries all SIRs were fairly close to 100 ; and the high SIR for deep collieries was reflected in each cause group. The most noticeable gradients were for psychoses and psychoneuroses $(74,93,137)$ and acute bronchitis $(84,92,127)$.
Mechanization The only SIR to show a pattern was that for influenza $(109,107,104,88$ from the lowest degree of mechanization to the highest) but this is probably only a chance finding.

Financial responsibility The clear trend shown in Table 10 was maintained with considerable consistency for specific causes.

Pneumoconiosis Because there is very little pneumoconiosis among those under 35, SIRs for this comparison were based on the age group 35-64. The all causes gradient was found to arise from corresponding gradients for 'other respiratory illnesses', acute bronchitis, and influenza; on the other hand, those with definite pneumoconiosis had slightly low incapacity from acute respiratory infections, arthritis, and rheumatism.

\section{Discussion}

The method of sampling, the size of the sample, the fact that the information was provided by the employers, and the evidence presented all indicate that the NCB sample census population was truly 
representative of employed miners. The national census figures for those 'economically active' are at considerable variance, largely because about onesixth of those listed as in coalmining occupations had given inadequate descriptions.

Over a quarter of industrial males employed by NCB were in occupations not specific to coalmining (and so did not code to 010-012). Many men not doing ordinary mining jobs call themselves miners as a badge of honour (Stevens, 1962). These facts did not lead to error in the present enquiry but they affect occupational statements on census schedules, claims for benefit, and at death registration (Heasman, Liddell, and Reid, 1958; Liddell, 1973).

Nowadays, the British mining industry is much more highly mechanized than in 1961. However, seam thickness does not change rapidly and the proportion of face workers has not been greatly affected by mechanization. Thus approximately half the face workers of the industry have to lie or kneel at work. Although it might have been expected that age distributions would be affected by mechanization this was not found to be so. Accident and absence rates were not greatly affected by mechanization, probably because they both tend to reflect differences in reporting and recording (Liddell and May, 1958; Buzzard and Liddell, 1963).

Men in the mining industry clearly had very high rates of incapacity. The ratios quoted in Table 8 ranged up to 273; all but two were above 150 . In MPNI (1965), ratios over 150 occurred in only seven occupational groups (out of nearly 200), i.e., five groups of labourers (including those coded 188, which embraced 'general workers' on the surface) with ratios between 200 and 153; bus and tram conductors (ratio 155); and a group of 23 chimney sweeps.

The excess, shown in ratios 182 for inception rates (persons) and 217 for days (from MPNI, 1965), appears to have been of a similar order to that in 1951 and in 1955-56-ratios (spells) 226 and 282 (Liddell, 1962)-bearing in mind that the persons ratio is most inert, i.e., shows least variation between groups of people compared with other indices, and that for spells the most volatile (Logan and Brooke, 1957 , p. 35). However, the absolute rate of incapacity among miners appears to have increased. For 1951, it was estimated as about 76 spells per hundred men in coalmining occupations and in 1961-62 it was 119 (Table 11).

There were clear differences between men in different types of mining employment and between grades (reflecting rates of pay) within place of work. Men not in specific coalmining occupations had higher incapacity than those in similar occupations in other industries, as this summary of ratios expected ${ }^{1}$ and observed (Table 8 ) shows:

\begin{tabular}{|c|c|c|c|}
\hline \multicolumn{2}{|c|}{$\begin{array}{c}\text { Occupations not specific to } \\
\text { coalmining }\end{array}$} & \multicolumn{2}{|c|}{ Expected $^{1}$ Ratio Observed } \\
\hline Face. . & .. Craftsman & 93 & (214) \\
\hline $\begin{array}{l}\text { Elsewhere- } \\
\text { underground }\end{array}$ & $\begin{array}{l}\text { Craftsman } \\
\text { Other }\end{array}$ & $\begin{array}{l}100 \\
127\end{array}$ & $\begin{array}{l}169 \\
256\end{array}$ \\
\hline Surface & $\begin{array}{l}\text { Craftsman } \\
\text { Other }\end{array}$ & $\begin{array}{r}98 \\
145\end{array}$ & $\begin{array}{l}125 \\
209\end{array}$ \\
\hline Workshop staff & . & 109 & 159 \\
\hline
\end{tabular}

${ }^{1}$ Estimated from the figures code by code in MPNI (1965). Although the estimates contain a considerable element of doubt, there is no question that the upper bound for the expected ratio is in each case substantially below the observed ratio.

Certain of the effects found may reflect differences in hazard (type of employment, size of community, depth of working, pneumoconiosis), others appear to be largely social in origin (rate of pay, financial responsibility, coalfield), and there were no relations with mechanization.

The arduousness of work is greatest at the face and least on the surface; this was reflected in spells of incapacity, but not in days or in long spells (Fig. 2). Under-officials, who have responsibilities similar to those of foremen, had high incapacity rates. But they have an active job; in addition to their production duties they have, by law, to make at least two inspections of their entire district during a shift. Again, a better sick pay scheme than for the other underground workers might have contributed to the excess. Workshop staff with low absence rates have been found elsewhere, e.g., in the General Post Office (Reid, 1968).

Low incapacity rates in rural areas were as expected, but no explanation is offered for the trend within urban areas; it is not explained by differences between coalfields. In five of the six coalfields in which there are conurbations, their SIR was lower than for any other size of community: the exception was Scotland where the conurbation SIR was highest.

The gradients in relation to depth of working, particularly for psychoses and psychoneuroses, are suggestive. The temperature of the working environment underground is fairly closely related to depth of working and there may be heat stress at work in the deepest collieries. It is unfortunate that figures are not available at the extremes.

It is not surprising that miners with pneumoconiosis should suffer more than others from acute bronchitis and 'other respiratory illnesses'. It is possible that the few slight shortfalls reported may have arisen only as a balance to the marked excesses.

In 1961 , roughly $2 \frac{1}{2} \%$ of industrial workers in the mining industry would have had a weekly rate of 
benefit for industrial injury greater than their weekly wage rate, but sickness benefit was on a considerably lower scale so that none would gain financially by being sick. Thus benefit payments cannot explain the considerably higher incapacity among the lower grades compared with those at higher wage rates within each place of work. On the other hand, the lower grade of work was less skilled, involving less responsibility, and the explanation may lie herein. Benefit payments may be a factor nowadays, because some workers on the lowest wages and with large families may gain while sick, according to Archibald (1968) who pointed out that the situation 'becomes progressively more complex as additions to the country's social security legislation attempt to eliminate hardship and yet maintain some sort of relationship to the whole'. Again the fact that high rates of incapacity among men with large families extended through a wide range of diseases may lend support to the suggestion that the father was required at home to help with a sick family.

Differences between coalfields in incapacity existed not only for all causes but for each specific cause; and when account was taken of each factor studied. There is no obvious explanation, but they may possibly have arisen from differences in selection, migration, habits of consulting the physician, or practices of medical care, particularly in relation to general practitioners' standards of fitness for mining and so of certification.

Finally, while the lack of association between incapacity and mechanization may be surprising, it suggests that the major changes in the industry since this study may not have affected greatly the patterns of miners' morbidity, particularly as distributions by age, place of work, etc., may also not have been greatly changed by mechanization.

A fair comparison between miners and others would be based on miners without pneumoconiosis, at the least hazardous depths of working. On the other hand, type of employment, wage rates, etc., are typical of the industry. Lastly, we have to assume that sizes of family are not too dissimilar, that distributions over size of community are not widely different, and that all the relevant effects are independent of each other. On these bases incapacity rates in Scotland would be about $62 \%$ of those for the whole industry (found by multiplication of the relevant SIRs). Applying this to the equivalent average ratios of Table 7 would bring the ratio for face workers to 123 , a little above that for very arduous non-mining occupations; this quite small excess could have arisen from the generally recognized additional difficulty experienced by the faceworker in reaching his work place compared with men in other arduous occupations. It would also bring the ratios for occupations not specific to coalmining not too far out of line with the cal- culated expectations (bearing in mind all the assumptions and approximations). It would still leave under-officials, elsewhere-underground workers (011), and surface workers (012) with high ratios $(146,159$, and 171).

Thus it might appear that:

(a) face workers without pneumoconiosis, and in the least hazardous conditions, had incapacity in line with the extremely arduous nature of their work;

(b) pneumoconiosis, and perhaps deep workings, led to additional incapacity;

(c) under-officials and those in the lower paid jobs underground and on the surface suffered excess incapacity, apparently for reasons associated with social factors, perhaps even including morale;

(d) for unexplained reasons, there was further excess incapacity in most English coalfields, and even greater excess incapacity in Yorkshire and South Wales.

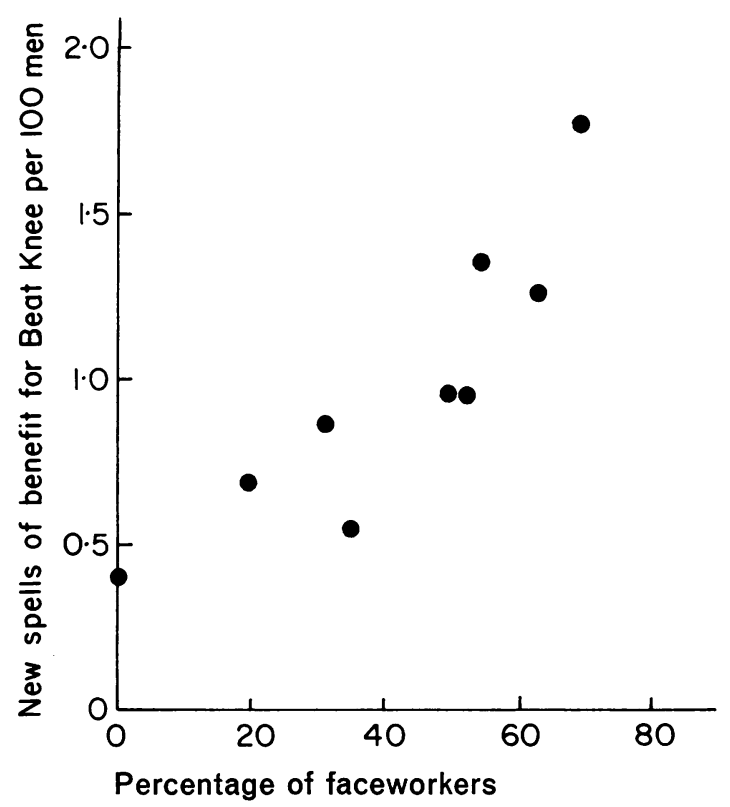

FIG. 3. Beat knee and seam height in the nine NCB Divisions. Face workers working at collieries where average seam height was 30 to 49 inches.

A final comment is needed on the other health hazards of miners. They suffer very much more than average from the prescribed occupational diseases, but the direct effects on incapacity are small in relation to those already discussed. The beat diseases cause most spells of absence. Figure 3 shows that beat knee was closely related to seam height; 
however, for the industry as a whole, this condition caused only 1.0 spell per 100 men in 1961 , while the other beat diseases, tenosynovitis, dermatitis, and nystagmus, accounted for a further 0.8 spells (from Rogan, 1964) compared with 119 for sickness (Table 11). Definite pneumoconiosis was diagnosed in $5.1 \%$ of working miners, but this condition does not directly cause incapacity for work until it is well advanced. Miners also had very high rates of injury (32 spells of benefit per 100 men; from NCB, 1962) in 1961, but 'non-occupational' sickness remains the major cause of incapacity for work.

Most of this work was carried out while I was head of Medical Statistics Branch, National Coal Board, and I thank the Board and particularly Dr. J. M. Rogan, Chief Medical Officer, for facilities and encouragement. Special thanks are due to Miss G. M. Jones, Mr. D. Newman, and Mr. L. W. King, of the then Ministry of Pensions and National Insurance, and to Mr. G. F. P. Boston of the then General Register Office. Advice was readily available from the Board's Research Advisory Panel on Epidemiology (chairman: Professor D. D. Reid), Dr. Rogan, and Dr. J. S. McLintock, Deputy Chief Medical Officer, NCB. I am very grateful to Dr. R. Murray, Medical Adviser to the Trades Union Council, for providing the classification of occupations. Great assistance was given by the NCB Statistics Department (in particular, the late Mr. R. F. George, the late Mr. F. W. Robbins, and Mr. E. C. Foulger) and Computer Services (Mr. R. A. Hitchcock, Mr. F. Nixon, Mr. H. Alsop, Mr. D. Black, and Mr. B. Glass). I wish to thank especially Mrs. E. D. Baxter and Mrs. J. E. Gray and their staff for their vital help. The views expressed are my own and must not be taken as those of any person or organization mentioned above.

\section{References}

Archibald, R. McL. (1968). Personal communication.

Buzzard, R. B., and Liddell, F. D. K. (1963). Coalminers' Attendance at Work. Med. Res. Memor. 3, National Coal Board Medical Service, London.

Cornwall, C. J. (1962). Discussion in Liddell (1962), pp. 24-25.

General Register Office (1960). Classification of Occupations 1960. H.M.S.O., London.

- (1966). Census 1961, England \& Wales. Occupation Tables, p. 7. H.M.S.O.

General Register Office, Edinburgh (1966). Census 1961, Scotland, vol. VI. Occupation, Industry and Workplace, Part I: Occupation Tables, p. 8. H.M.S.O.

Heasman, M. A., Liddell, F. D. K., and Reid, D. D. (1958). The accuracy of occupational vital statistics. Brit. J. industr. Med., 15, 141-156.

Liddell, F. D. K. (1954). Attendance in the coal-mining industry. Brit. J. Sociol., 5, 78-86.

(1955). Colliery statistics. J. roy. statist. Soc. A, 118 405-416.

(1960). The measurement of occupational mortality. Brit. J. industr. Med., 17, 228-233.

(1962). Coalminers' morbidity. J. roy. statist. Soc. $A, 125,1-29$.

(1973). Mortality of British coalminers in 1961. Brit. J. industr. Med., 30, 15-24.
- - and May, J. D. (1958). A statistical study of coal-mining accidents. Brit. J. industr. Med., 15, 262-269.

Logan, W. P. D., and Brooke, E. M. (1957). The Survey of Sickness 1943 to 1952, General Register Office, Studies on Medical and Population Subjects No. 12. H.M.S.O., London.

Ministry of Pensions and National Insurance (1965). Report on an Enquiry into the Incidence of Incapacity for Work, part II: Incidence of Incapacity for Work in Different Areas and Occupations. H.M.S.O., London.

Murray, R. (1967). Personal communication.

National Coal Board (1962). Annual Report and Statement of Accounts, 1961. H.M.S.O., London.

Reid, D. D. (1968). Personal communication.

Rogan, J. M. (1964). Medical Service and Medical Research: Annual Report 1963. National Coal Board (Medical Service), London.

Stevens, B. (1962). Discussion in Liddell (1962), pp. 23-24.

World Health Organization (1957). Manual of the International Statistical Classification of Diseases, Injuries and Causes of Death based on the Recommendations of the Seventh Revision 1955. W.H.O., Geneva.

Yule, G. U. (1934). On some points relating to vital statistics, more especially statistics of occupational mortality. J. roy. statist. Soc., 97, 1-26.

\section{Appendix}

\section{Methods}

One card was created for each NCB employee at 5 June 1961 whose National Insurance (NI) no. ended in $4 \mathrm{~B}$ or $8 \mathrm{~B}$. A check was made locally that the numbers of cards were as expected in a $5 \%$ sample and local NI offices coded residence; 33156 cards were received; after being coded, punched, and edited, they were passed in May 1962 to MPNI, who found that 495 should not have been in the sample (of these 403 were females with NI nos. ending in 8B) and there were 49 duplicates. At the end of 1962 , MPNI supplied duplicate cards (excluding names and addresses) for all 32612 NCB employees they had included in their own enquiry. Further checking revealed problems of identification in 30 cases, and inadequate data or other edit failures meant that a further 401 had to be excluded from the NCB census tape, which thus contained 32181 records. These 431 unexplained errors amount to $1.3 \%$ of 32 612. The tape was written in May 1964 after colliery details had been obtained from the Colliery Profile (Liddell, 1955), here called CP.

In mid-1963, MPNI supplied 36816 cards, one for each spell of incapacity for all persons in the NCB census. Many errors of reproduction had to be cleared, and a merged census/incapacity tape could not be created until March 1965.

Meanwhile it had become clear that information about non-miners in the MPNI report would not allow full comparison with miners. Further material was therefore borrowed from MPNI, but serious errors were made in writing it on to tape, so that the tapes had to be abandoned; and by then the necessary cards were not still available in MPNI. However, all the programs for analysing NCB tapes had been 
written, which meant that NCB and MPNI tabulations would not all be on the same bases.

At the end of 1966, all tabulations had been prepared but study revealed certain discrepancies that took many months to elucidate. In the event, it was found that most of the information had been carried forward perfectly, but some re-coding was necessary and 12 more records had to be excluded. More important, incapacity among men working in drifts and in the deepest collieries could not be salvaged. The final tape was ready at the end of 1967 , and the tabulations that had to be re-run were received in 1968 and thereafter necessary consolidation, summarization, calculations of rates, etc. were carried out.

The population Of the 32181 persons on the census tape, 325 were females and 2772 were non-industrial males, leaving 29084 industrial males. Of these, 12 had been omitted from the merged tape and 470 were over 64, leaving 28602 men for the study of incapacity.

Occupations The General Register Office (1960) codes for coal mining occupations make certain exclusions. It was found that the main occupations which did not code to 010-012 were: craftsmen (153 at the face, 1379 elsewhere-underground and 1310 on the surface); conveyor operators, haulage enginemen, and others concerned with transport (of whom there were 185 at the face, about 1200 elsewhereunderground, and perhaps 500 on the surface) and, on the surface, general workers (numbering 1026 ) whom MPNI classed as labourers (code 188).

Size of community The coding by local NI offices of each man's address allowed grouping as follows: rural areas; small towns (urban areas, populations less than 50000 ); large towns (urban areas, populations 50000 or more); and conurbations. The basis of Table 3 is the 29072 men on the merged tape, less one with unknown size of community, and of Table 10 it is the available 28601 men aged 15 to 64 .

Size of colliery Small, medium, and large collieries were defined as those employing less than 500 men, 500 to 1999 men, and 2000 or more men. Table 4 is based on 29084 men.

Depth of working Information (from CP) was not available for a small number of collieries and hence for the men working there. Table 4 is based on the remaining 17687 workers at the face and elsewhereunderground. There is a slight overstatement of men at drifts because of a programming error. Collieries where access was by shaft were defined as shallow, medium or deep where average depth of working (yards) was less than 400,400 to 599 , and 600 or more. A further programming mistake meant that on the incapacity tape it was not possible to distinguish men working in drifts or in the deepest collieries or at unknown depths. Table 10 is based on 20668 men in collieries, with access by shaft, classified as very shallow, shallow or deep where average depth of working (yards) was less than 300 , 300 to 499 , and 500 to 699 .

Posture at work and seam thickness From CP data, the predominant posture at the face was inferred, based on observations in Buzzard and Liddell (1963, p. 109) as lying, kneeling, stooping or standing where average seam thickness (inches) was less than $30,30-49,50-69,70$ or more.

Degree of mechanization Shortfalls in this CP material arose as for depth of working. Table 5 is based on 10218 face workers (only 1 short), Tables 4 and 6 on 19226 underground workers (33 short), and Table 10 on 27198 men ( $5 \%$ short). The degree of mechanization was assessed as very low, low, medium or high when the proportion of output won from mechanized faces $(\%)$ was less than 10 , $10-39,40-69,70$ or more.

Accident and absence rates Each colliery's rate (from CP) was used to obtain averages, by weighting according to the number of men at the collieries in each classification of mechanization when the information was available: 20983 workers underground were used for the weighting of accident rates and 27661 men for absence rates.

Financial responsibilities The distribution of men by income tax PAYE codes shows peaks close to the codes corresponding to the allowances: personal, personal plus wife plus zero, one or more dependent children. The troughs are low. Thus the codes can be used to infer financial responsibilities (cf. Liddell, 1954; Liddell, 1962; Buzzard and Liddell, 1963). The 'emergency' code $\mathrm{E}$ was recorded for 197 men, 147 being under 20, who were omitted from the assessment. Figure 1 is based on all the other 28887 men and Table 10 on 28266 . Size of family includes the miner, his wife, and any dependent children.

Arduousness of work Dr. R. Murray, Medical Adviser to the Trades Union Congress, provided a classification of arduousness for every occupation listed in the General Register Office (1960) classification.

Length of spell The distributions of spells of incapacity by duration were similar to those reported by Liddell (1962) and the same definitions of lengths 
were used: long spells were those lasting 22 or more working days (three and a half weeks or more).

SIRs Rates of incapacity, in terms of spells per 100 men, were standardized for age on the basis of the age-specific (and where appropriate causespecific) incapacity rates of Table 11, by the 'new' method described by Liddell (1960). Because of small numbers in the younger age groups, some SIRs were based only on older men.

Cause of incapacity Dr. J. S. McLintock, Deputy Chief Medical Officer, NCB, provided the following classification of cause, using the WHO (1957) codes then in use:

$\begin{array}{ll}\begin{array}{ll}\text { Acute upper respiratory } \\ \text { infections }\end{array} & 470-475 \\ \text { Influenza } & 480-483 \\ \text { Acute bronchitis } & 500-501 \\ \text { Other respiratory illnesses } & 241,490-493,502, \\ & 510-528,783 \\ & 720-727 \\ \text { Arthritis and rheumatism } & 363,734,741, \\ \text { Injuries } & \text { E800-E999 } \\ & \\ \text { Gastritis, duodenitis, and } & \\ \quad \text { disorders of the functions } & \\ \text { of the stomach } & 543-544 \\ \text { Gastroenteritis } & 048,571,779 \\ \text { Ulcers } & 540-542 \\ \text { Psychoses and psycho- } & 300-318 \\ \quad \text { neuroses } & 690-716 \\ \text { Skin conditions } & \\ \text { Diseases of the heart and } & 400-450 \\ \text { arteries } & 140-239,330-362, \\ \text { 'Reference diseases' } & 364-365,367-369, \\ & 550-553,590-617 \\ & \text { Remainder }\end{array}$

'Reference diseases' These are conditions which, as far as possible, are not occupational in origin, are of unequivocal diagnosis, and cause disability, for any occupation, for a substantial period. Thus there should be no differences between groups of men in long spells of incapacity from reference diseases: no trace of significant differences could be found in any of the comparisons discussed in the paper. However, rates based on all spells of reference diseases tended to follow the patterns for all causes, but much less detinitely and without indication of statistical significance. These facts provide confirmation of the procedures.

Pneumoconiosis The master file tape of the NCB Periodic $x$-ray Scheme (Rogan, 1964) was searched for records in 1959-63 of all the men in the sample census; $19684(68 \%)$ were traced. (The difference from the $85 \%$ response rate achieved by the Scheme lies in labour turnover.) Close correspondence was found in the prevalence of each category of pneumoconiosis coalfield by coalfield in the 19684 men traced and in the overall industry results for 500000 men surveyed, 1961-63. Table 10 is based on the 14171 men aged 35-64 whose $x$-ray was traced.

Reliability As the material for the NCB census came mainly from the same sources as provide routine statistics, close agreement was to be expected. Wherever possible, comparisons have been made with published (NCB, 1962) and unpublished official NBC material; all differences could be accounted for by sampling variation and by known differences in definitions, etc. The patterns of Fig. 1 are so much what might be expected that financial responsibilities are considered to have been satisfactorily assessed also. The incapacity ratios in Table 8 for codes 010 and 011 are very close to those in the MPNI enquiry; they are based on essentially the same men. The ratio for 012 is rather lower in the MPNI enquiry, which included under this code about $20 \%$ more men than the NCB. Although in some of the detailed comparisons described certain men had to be excluded, the reasons were unconnected with the subject of the enquiry, and there is no reason to believe that any of the exclusions led to bias. In other words, the relativities described are considered reliable.

Received for publication February 4, 1972. 